\title{
ASSESSMENT PLOT RISK OF CONTAMINATION OF THE WATERS OF THE COUFFO RIVER BY PESTICIDES IN THE COTTON BASIN OF THE COMMUNE OF DJIDJA
}

\author{
Firmin H. AIKPO and Norbert AGOINON \\ Department of Geography and Regional Planning, FLASH, UP, B.P. 123 \\ https://doi.org/10.35410/IJAEB.2021.5668
}

\begin{abstract}
In the commune of Djidja, the intensification of agriculture is an important factor in the use of pesticides. Research has shown the contamination of the aquatic ecosystem by pesticides in this environment. The objective of this research is to assess plot risk of contamination of the waters of the Couffo River by pesticides in the cotton basin of this town. Surveys on agricultural practices were conducted with 55 producers in three villages (Zakan-kossossa, Fonkpodji and Aklinmè), all located in the cotton basin. It is also adopted within the framework of this research, the methods of multi-criteria analysis of decision support. The results showed that, per treated area, $29.09 \%$ of producers applied dose of pesticides higher than that registered, $61.82 \%$ of respondents used a dose of pesticides lower than that recommended and $09.09 \%$ of the latter respected the normal dose. As for the assessment of the plot risk of contamination of the waters of the Couffo River, it is noted that the type 1 and 2 plots present a medium risk, the type 3 plots a low risk and those of types 4, 5, 6 and 7 very low risk. It is also essential to assess the risk of climatic and biogeochemical factors in order to better understand the risk situation for the sustainable management of this river.
\end{abstract}

Keywords: Risk-plot-contamination-river-pesticides.

\section{INTRODUCTION}

In Benin, the agricultural sector plays a major role in economic and social growth because of its contribution to the creation of wealth and employment. Indeed, the Beninese agricultural sector, which employs around $70 \%$ of the working population, contributes nearly $23 \%$ to the formation of the GDP and provides around 75\% of export earnings and 15\% of State revenue (MAEP, 2017: 7). It is recognized as an important sector for ensuring food sovereignty and food and nutrition security, but also for increasing income. To meet these major challenges, Benin is implementing various policies and development strategies for the agricultural sector. But, if the performance of this sector in recent years seems quite interesting, the import and massive use of chemical fertilizers and pesticides that characterize it, worry and rightly challenge scientists, consumers, farmers' organizations and organizations of the civil society in the environmental and agricultural sectors in Benin (R, Sègbènou, 2018, p.3). The leading West African cotton producer since 2018, Benin has made substantial progress in its harvests of white gold, but also soybeans, peanuts and rice (G, Dossouhoui, 2021, p. 1). The concern to increase agricultural production and productivity (especially cotton), leads governments and farmers to turn to the massive use of chemical molecules of pesticides and fertilizers as varied as they are dangerous. during the 20202021 crop year would amount to 4,864,789 liters including 2,859,267 liters of herbicides and 2,005,522 liters for other pesticides (insecticides, acaricides, etc.) and the cotton sector's share 
Vol. 06, No. 05; 2021

ISSN: $2456-8643$

amounts to $99.6 \%$ of these pesticides, i.e. approximately 2,857,104 liters of herbicides and $1,988,508$ liters for other pesticides (INSAE, 2020, p.15). In the municipality of Djidja, the intensification of agriculture is an important factor in the use of pesticides. The objective sought in the use of these chemicals remains an increase in the productivity of the exploitable plots of land by the elimination of crop predators. The quantity of pesticides used was estimated at more than 90,000 tonnes (2013-2014 crop year) in this commune and this, only on cotton crops (F, Aikpo, 2016, p. 146). Cotton fields and other crops are sometimes installed there not far from the banks of the rivers and are often treated with pesticides. Research has shown the contamination of the aquatic ecosystem by pesticides in the municipality of Djidja. Indeed, catfish (Clarias gariepinus), crabs (Cardiosomaarmatum), toads (Bufforegulatis) and frogs (Xenopus muelleri) collected in Dridji and analyzed revealed the presence of pp-DDE at a content of 403ng / $\mathrm{g}$ and endosulfan at a content of 75ng / g (L, Glinet al., 2006, p. 13). Likewise, sediments and aquatic organisms from the Kiti river, collected and analyzed by E, Pazouet al. (2014, p. 8892), showed the presence of the metabolites of DDT with levels of $5.14 \mu \mathrm{g} / \mathrm{kg}$ of weight for the sediments of this river, and the compounds of DDT such as $\alpha$-endosulfan, reached levels of $403 \mathrm{ng} / \mathrm{kg}$ of lipids in fish, crabs and amphibians. In the same section, the analysis of water samples from the Couffo river (F, Aikpo et al., 2015, pp. 1727-1728), taken in this municipality, highlighted water contamination by the glyphosate $(0.105-0.221 \mu \mathrm{g} / \mathrm{L})$, profenofos $(0.012-0.105 \mu \mathrm{g} / \mathrm{L})$, acetamiprid $(0.043-0.082 \mu \mathrm{g} / \mathrm{L})$ and cypermethrin $(0.095-0.113 \mu \mathrm{g} / \mathrm{L})$. Tilapiasguineensis collected in this river and analyzed by F, Aikpo et al. (2017, pp. 1358-1359) revealed average levels of glyphosate $(0.118-0.191 \mu \mathrm{g} / \mathrm{kg})$; in profenofos $(0.095-0.125 \mu \mathrm{g} / \mathrm{kg})$; in acetamiprid $(0.112-0.125 \mu \mathrm{g} / \mathrm{kg})$ and in cypermethrin $(0.127-0.139 \mu \mathrm{g} / \mathrm{kg})$. Various factors regulate the transfer of pesticides to surface water. These are structural factors (topography, distance of the plot from the watercourse), human (agricultural practices), climatic (the typology of rainfall in the watershed and their influence on spatial and temporal variability) and biogeochemical (the importance and variation of dissolved and particulate organic matter contents and the presence of microorganisms and their influence on the adsorption, desorption and degradation of pesticides), explained E, Charbonnier et al. (2015, p. 67). The objective of this research is to assess the risk of contamination of the waters of the Couffo River by pesticides in the cotton basin of the municipality of Djidja.

\section{MATERIAL AND METHODS Study framework}

The municipality of Djidja is one of the nine (09) municipalities of the Zou department. It is the largest municipality in this department. Located between 7o10, and 7o40, north latitude and between 1040, and 2o10, west longitude, this commune covers $41.66 \%$ of the total area of the Zou department, or $2184 \mathrm{~km} 2$ and is limited to the north by the Collines department. (commune of Savalou), to the south by the communes of Abomey and Bohicon, to the southwest by the department of Couffo (commune of Aplahoué) and the Republic of Togo, and to the east by the communes of Za- Kpota and de Covè (INSAE, 2013: 11). This commune enjoys a climate of transition between the subequatorial climate of the coast and the tropical climate of the SudanoGuinean type of northern Benin; its relief is made up of a plateau with depressions, but also granite outcrops, and it is drained by $145 \mathrm{~km}$ of waterways, of which the Zou river and the Couffo river are the most important. (L, Akomagni, 2006, p.11). The types of soils in this 
Vol. 06, No. 05; 2021

ISSN: $2456-8643$

environment are: ferrallitic soils, tropical ferruginous soils, vertisols and hydromorphic soils (SDS, 2004, p. 10) and the vegetation is made up of several formations such as palm groves, shrub savannah, wooded savannah, forest islands and forest galleries.

\section{METHODS}

Several complementary methodological approaches are used in the context of this research.

\section{Data collected}

The land use map (map1) is produced from the extraction of the Digital Terrain Model (DEM) of topographic maps at 1 / 600,000 and land use at 1: 95,000, produced by CENATEL in 2004, and also observations in the field.

Surveys on agricultural practices (the area of the plots, the main formulations of pesticides used, the dose of pesticides applied per area treated and the frequency of treatment of the plots) were conducted with 55 producers in three villages (Zakan-kossossa, Fonkpodji and Aklinmè), all located in the cotton basin.

\section{Plot risk assessment criteria used}

To assess the risks of contamination of surface water by pesticides, a multi-criteria method of the contribution of plots to these risks is implemented (N, Aouadi, 2018). It is adopted within the framework of this research, the method of multicriteria analysis of decision support. Although initially developed to solve decision-making problems of an economic, financial or spatial planning nature, this method is now used in many cases, especially for environmental questions (S, Chakhar, 2006, p. 10; R , Greene et al., 2011, p. 416; F, Macary et al., 2010, p. 36: 2014, p. 82). The criteria defined and prioritized for this search are as follows:

- The distance of the plots from the watercourse: this is estimated by taking into account the distance between the bottom of the plot in question and the Couffo river. Classes are determined (0m; <50m; 50-200m;> 200m).

- The slope: it is considered by taking into account as a criterion, the average of the slopes of the plot. Class thresholds are retained (<3\%; 3-5\%: $5 \%)$.

- The length of the plot: it is calculated in the direction of the slope and gives an indication of the size of the contributory surface treated. Thresholds are adopted $(<50 \mathrm{~m} ; 50-150 \mathrm{~m} ; 200 \mathrm{~m})$.

- Downstream protection of the plot: the presence of buffer space (grassy strip, forest) or its absence are the two methods used for this criterion.

\section{RESULTS}

Each active substance is registered via an application rate per hectare, which may vary depending on the crop or the target. Table I presents the results of the surveys on the main formulations used by producers and on the dose of pesticides applied per cultivated area for different crops. 
Vol. 06, No. 05; 2021

ISSN: $2456-8643$

Table I: Dose of pesticides applied per hectare.

\begin{tabular}{|lccc|}
\hline Pesticides & $\begin{array}{c}\text { Doses appliquées } \\
(\mathbf{L} / \mathbf{h a})\end{array}$ & $\begin{array}{c}\text { Doses homologuées } \\
(\mathbf{L} / \mathbf{h a})\end{array}$ & $\begin{array}{c}\text { Nombre de } \\
\text { producteurs }\end{array}$ \\
\hline Cutter 112 EC & 0,375 & 0,250 & 4 \\
Profénofos 500 EC & 0,75 & 1 & 7 \\
Epervier 220 EC & 4 & 5 & 2 \\
Ema Super 56 DC & 0,5 & 0,5 & 2 \\
Thunder 145 O-TEQ & 0,3 & 0,2 & 3 \\
Tihan 175 O-TEQ & 0,3 & 0,2 & 2 \\
Coton Plus TM 88 EC & 0,75 & 0,5 & 7 \\
Nurelle D 335 EC & 1 & 1 & 3 \\
Cypercal P 30 EC & 0,75 & 1 & 5 \\
Kalach 360 SL & 2 & 3 & 8 \\
Glycel 410 SL & 2,5 & 3 & 5 \\
Glyphogan 360 SL & 2,5 & 3 & 4 \\
Glyphader 480 SL & 4 & 6 & 3 \\
\hline
\end{tabular}

This table indicates that $07.14 \%$ of producers applied a dose of Cutter $112 \mathrm{EC}$ higher than the recommended rate, $12.50 \%$ of producers applied a rate of Profenofos $500 \mathrm{EC}$ lower than the recommended rate, $03.57 \%$ of producers acknowledged that they had used a lower dose of Hawk 220 EC than recommended and $03.57 \%$ of growers adhered to the recommended dose of Ema super 56 EC. The rate of Thunder 145 O-TEQ (05.35\%) and Tihan 175 O-TEQ (03.57\%) applied by producers in each case exceeds the registered rate, $12.50 \%$ of producers used a rate of Coton Plus TM 88 EC higher than registered, $05.35 \%$ of the producers respected the rate of Nurelle D 335 EC approved and $08.92 \%$ of the producers used a rate of Cypercal P 330 EC lower than the standard. Regarding other pesticides, $14.28 \%$ of growers used a lower dose of Kalach 360 SL than recommended, $08.95 \%$ a lower dose of Glycel 410 SL than recommended, 07.14\% a Glyphogan 360 SL dose lower than registered and $05.35 \%$ of producers used less than recommended dose of Glyphader.

Overall, the treatment frequency index is low. The frequency of treatment is reduced to 4, 5, 6 or even 7 for cotton and to 2,3, 4 or 5 for cowpea.

The results of the assessment of the individual risk of contamination of the waters of the Couffop River by pesticides are as follows (Table II). 
Vol. 06, No. 05; 2021

ISSN: $2456-8643$

Table 2: Risk factors for contamination of the waters of the Couffop river by pesticides

\begin{tabular}{|c|c|c|c|c|c|}
\hline $\begin{array}{l}\text { Types of } \\
\text { plots }\end{array}$ & $\begin{array}{l}\text { Distances of the } \\
\text { plots in the water }\end{array}$ & Slopes & Plot lengths & $\begin{array}{c}\text { Downstream } \\
\text { protection of plots }\end{array}$ & Risks. \\
\hline 1 & $<50 \mathrm{~m}$ & $5-6 \%$ & $>300 \mathrm{~m}$ & $\begin{array}{l}\text { Protected by } \\
\text { vegetable crops }\end{array}$ & $\begin{array}{c}\text { Averag } \\
\mathrm{e}\end{array}$ \\
\hline 2 & $50-100 \mathrm{~m}$ & $4-5 \%$ & $200-250 \mathrm{~m}$ & $\begin{array}{l}\text { Not protected by a } \\
\text { grass strip }\end{array}$ & $\begin{array}{c}\text { Averag } \\
\mathrm{e}\end{array}$ \\
\hline 3 & $100-150 \mathrm{~m}$ & $3-4 \%$ & $150-200 \mathrm{~m}$ & $\begin{array}{l}\text { Protected by a } \\
\text { grassy strip }\end{array}$ & Weak \\
\hline 4 & $150-200 \mathrm{~m}$ & $2-3 \%$ & $100-150 \mathrm{~m}$ & $\begin{array}{l}\text { Protected by a } \\
\text { forest gallery }\end{array}$ & $\begin{array}{l}\text { Very } \\
\text { weak }\end{array}$ \\
\hline 5 & $200-250 \mathrm{~m}$ & $2-3 \%$ & $300 \mathrm{~m}$ & $\begin{array}{l}\text { Protected by a } \\
\text { forest gallery }\end{array}$ & $\begin{array}{l}\text { Very } \\
\text { weak }\end{array}$ \\
\hline 6 & $250-300 \mathrm{~m}$ & $2-3 \%$ & $200 \mathrm{~m}$ & $\begin{array}{l}\text { Protected by } \\
\text { grassy strip }\end{array}$ & $\begin{array}{l}\text { Very } \\
\text { weak }\end{array}$ \\
\hline 7 & $>300 \mathrm{~m}$ & $2-3 \%$ & $<200 \mathrm{~m}$ & $\begin{array}{l}\text { Protected by } \\
\text { grassy strip }\end{array}$ & $\begin{array}{l}\text { Very } \\
\text { weak }\end{array}$ \\
\hline
\end{tabular}

Analysis of this Table II shows that type 1 plots combine certain risk factors and only concern a few rare cases. They are located near the river and on an average slope. These are large plots, but not protected by crops that minimize water runoff with medium risk. Type 2 plots are found not far from the river with a slight slope. They are wide and not protected by a grass strip with a medium risk. Those of type 3 are relatively installed near the river, but their slope is weak. These 
plots are medium and protected by a grass strip and present a low risk. Type 4 plots are relatively observed near the river, on a low slope, of short length and very low risk. Type 5 and 6 plots are far from the river with a low slope. They are wide, protected by a grass strip and present a very low risk. Those of type 7 are identified very far from the river. Their slope is low. These are short plots, protected by a grassy strip and very low risk.

\section{DISCUSSION}

A gap is often observed between the use of pesticides recommended by a crop protection expert and that observed among producers. The results on the applied dose per hectare for the various pesticides showed that some producers did not apply the standard. We can therefore say that when it comes to the fight against parasites in the municipality, the adequacy is far from being achieved between peasant practices and the recommendations of the technical staff. The corollary of this practice is the low or the high concentration of pesticides. These results confirm the work of M, Akogbéto et al. (2005, p.401) on the use of agricultural insecticides in Benin. The type of crop gives the average number of pesticide treatments for each plot. We can also say that the application of pesticides against crop pests is not conditioned by the presence of these given the frequency of crop treatments ( 7 for cotton and 5 for cowpea in some cases). These results are consistent with those of A, Gomgnimbouet al. (2009, p. 501) in the Republic of Burkina Faso The flows of agricultural contaminants to surface water result from the complex interaction between agricultural activities, the nature of the soil, the climatic conditions and the structure of the watershed, to which in addition to the organization of the landscape (V, Gouy et al., 2008, p. 50). Topography is an element that intervenes in the process of transfers of pesticides to surface water. According to F, Laurent and J-P, Rossignol (2003, p. 158), topography guides the flow of water, the path and the amplitude of material flows. For example, these authors point out that it is obvious that 
International Journal of Agriculture, Environment and Bioresearch

Vol. 06, No. 05; 2021

ISSN: $2456-8643$

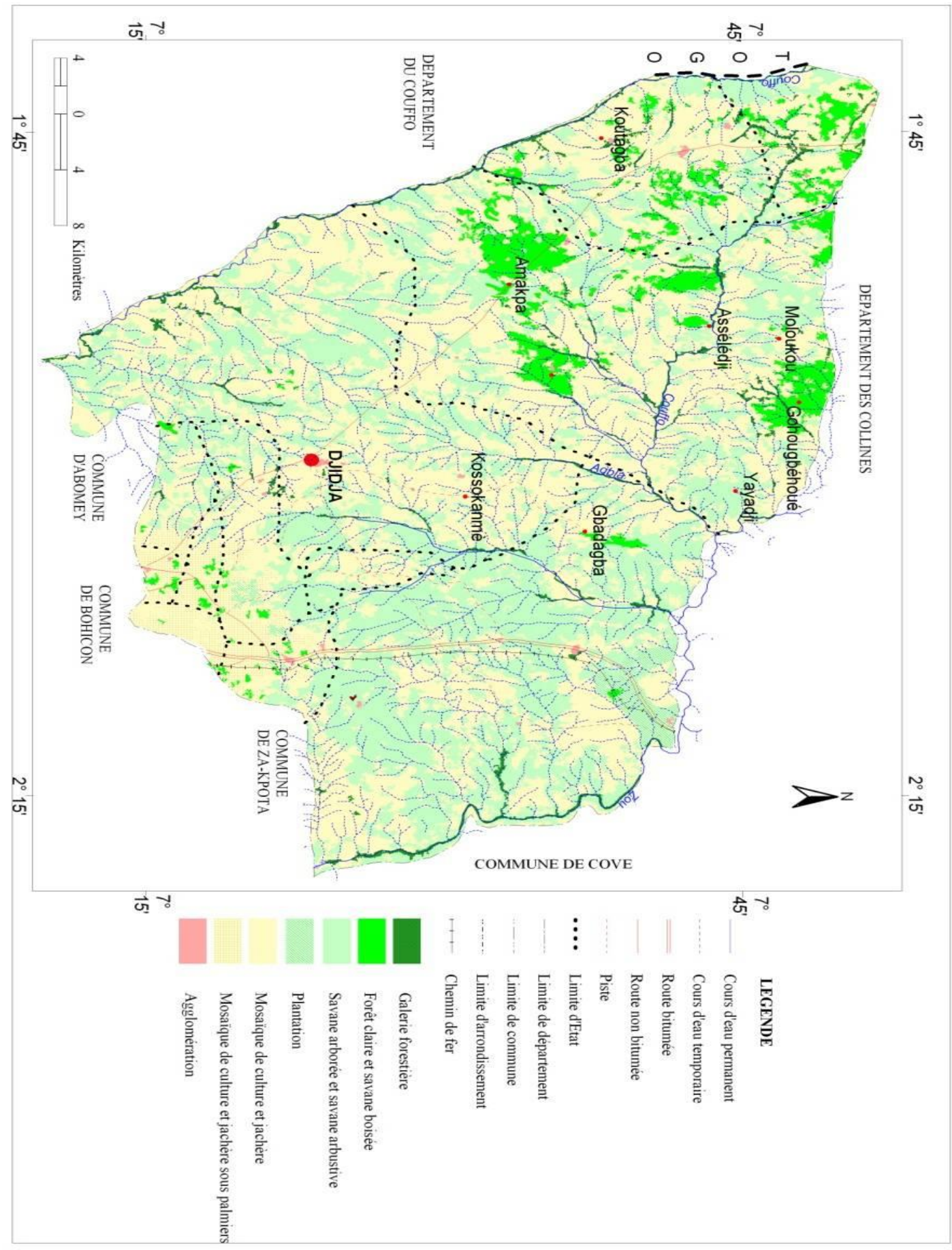




\section{REFERENCES}

Aikpo Firmin, ChabiChtistophe, Ayi Virgile, Koumolou Luc, Houssou Christophe, Edorh Patrick (2015). Assessment of the contamination of the waters of the Couffo river in the cotton zone of Djidja (Benin) by pesticides. Int. J. Biol. Chem. Sci. 9 (3): 1725-173.

Aikpo Firmin (2016). Use of pesticides in rural areas in Benin: state of the environmental situation in the municipality of Djidja. Doctoral thesis, UAC, 302p.

Aïkpo Firmin, AgbandjiLucien, AhouansèMiriacDimitri, KoumolouLuc, HoussouChristophe, Edorh Patrick (2017). Assessment of pesticides residues in fish (Tilapia guineensis) in the Couffo Riverin Djidja (Benin). International Journal of Environment, Agriculture and Biotechnology (IJEAB) Vol 2, Issue 3, 1356-1361.

Akogbéto Martin, Djouaka Rousseau, Noukpo Benoît (2005). Use of agricultural insecticides in Benin. Bull. Soc. Pathol. Exot., 98 (5): 400-405.

Akomagni Lazard (2006). Monograph of the municipality of Djidja. Support Program for the Start-up of Municipalities, Afrique Conseil, $44 \mathrm{p}$.

AouadiNawel, Macary Francis, Gaillard Juliette, Devier Marie-Hélène, BudzinskiHelen (2018). Risk assessment of surface water contamination by phytosanitary products: application to a wine-growing watershed (PhytoCOTE project). Contamination, environments, health and society. From risk assessment to public action. Toulouse, France, 12p.

Chakhar Salem (2006). Multi-criteria decisional mapping: formalization and IT implementation. Doctoral thesis, Paris Dauphine University, 300p.

Charbonnier Edwige, Ronceux Aicha, Carpentier Anne-Sophie, Soubelet Hélène, Batiuso Enrique (2015). Pesticides. From impacts to changes in practices, Quae editions, 403p.

CORPEN (2007). The environmental functions of buffer zones. The scientific and technical bases of the functions of water protection, First Edition, 75p.

Dossouhoui Gaston (2021). Report, Government of the Republic of Benin, 2p.

Glin Laurent, Kuiseu Julienne, VodouhèSimplice, Ferrigno Simon (2006). Living with Poison: Endosulfan Problems in West Africa Cotton Growing Systems, PAN UK, London, England, 48 p.

Gomgnimbou Alain, Savadogo Paul, Nianogo Aimé, Millogo-Rasolodimbi Jeanne (2009). Use of chemical inputs in a tropical agrosystem: diagnosis of the risk of environmental pollution in the cotton region of eastern Burkina Faso. BiotechnolAgron. Soc. Approx., 13 (4): 499-507.

Greene Randal, DevillersRodolphe, Eddy Brian (2011). GIS-Based Multiple-Criteria Decision Analysis.Geogr. Compass. 5 (6): 412-443.

Grill Jean-Joël, Carluer Nadia, Le Henaff Guy (2011). Buffer zones to limit water pollution by pesticides in watersheds. TSM number 7/8: 20-32. 
Vol. 06, No. 05; 2021

ISSN: $2456-8643$

Gouy Véronique, Gril Jean-Noël, Lacas Jean-Guillaume, Boivin Armand, Carluer Nadia (2008). Contamination of surface water by pesticides and the role of buffer zones in limiting transfer: state of knowledge and consequences for action. Engineering EAT no special, 49-63.

INSAE (2013). Results of the Fourth General Population and Housing Census (RGPH 4). Cotonou, Benin, $40 \mathrm{p}$.

INSAE (2020). Monograph of the "cotton" sector in Benin, 54p.

Laubier Florence (2001). The fragmented diagnostic method of the risk of surface water contamination by phytosanitary products in Brittany: foundations and implementation. EAT Engineering, no31, 91-98.

Laurent François and Rossignol Jean-Pierre (2003). Mapping of the water properties of soils from lithology and slopes. Application to the Moine watershed (Moine et Loire, France). Study and Management of Soils, 10.3, 155-170.

Macary Francis, Ombredane Dominique, Uny Daniel (2010). A multicriteria spatial analysis of erosion risk into small watersheds in the low Normandy bocage (France) by ELECTRE III method coupledwith a GIS.International Journal of Multicriteria Decision Making, vol. 2, no 1, 25-43.

Macary Francis (2014). Risk assessment of surface water contamination in agricultural watersheds. Multicriteria approaches by spatial modeling and multicriteria analysis for decision support. Doctoral thesis of the National Polytechnic Institute of the University of Toulouse, 183 p.

APRM (2017). Programmatic framework for the agricultural sector, validated version, 153p.

NollDorothea, Dakhel Nathalie, Burgos Stéphane (2010). Assessment of the risks of pesticide transfer by surface runoff. Swiss Agronomic Research 1 (3): 110-117

Pazou Elisabeth, Glin Laurent, VodouhèSimplice, Fanou Joseph, Swart Kees, van Gestel Cornelis (2014). Pesticide contamination of the Dridji cotton area in the Republic of Benin. African Journal of Food, Agriculture, Nutrition and Development, 14 (3): 8885-8902.

Sègbènou René (2018). Pesticides and chemical fertilizers in Benin, the Stop pesticide collective speaks out, ECO-BENIN, 7p.

SDS (2004). Summary document, Diagnosis, Vision and Project Planning for 2004-2008 in the sector of agriculture, animal husbandry and the exploitation of natural resources in the municipality of Djisja, PADeCOM / Zou, 159 p. 